\title{
Assessment of the Lowland Bog Biomass for Ex Situ Remediation of Petroleum-Contaminated Soils
}

\author{
Dmitriy V. Tarabukin 1
}

Institute of Biology, Komi Science Center, Ural Branch of Russian Academy of Sciences (IB FRC Komi SC

UBRAS), Kommunisticheskaya Str. 28, 167982 Syktyvkar, Russia; dim1822@yandex.ru

Received: 3 September 2020; Accepted: 6 October 2020; Published: 8 October 2020

\begin{abstract}
Bog petroleum-contaminated soils have been remediated ex situ in conditions close to natural ones. It was found that during the first 30 days in natural conditions, the decomposition of total petroleum hydrocarbons (TPH) was $30 \pm 5 \%$. On the 60th and 90th days, the process of TPH decomposition was $45 \pm 5 \%$ and $60 \pm 5 \%$, respectively. The effect of various stimulant supplements was negligible. For the entire observed period, bog soil showed a very high self-cleaning potential with pollution concentration of $5 \mathrm{~g}$ of petroleum per $100 \mathrm{~g}$ of soil sample. Such diagnostic indicators of soil condition as urease and cellulase activities turned out to be most sensitive in the bog soil. The introduction of mineral fertilizers to stimulate the TPH decomposition increased the activity of urease in comparison with the background soil. On the other hand, the nonionic surfactant acted as an inhibitor of microorganisms involved in nitrogen metabolism, even in the presence of mineral fertilizers. The introduction of mineral fertilizers to petroleum-polluted bog soil stimulated the cellulases activity, while surfactants suppressed them in the early stages. The simultaneous introduction of surfactants and fertilizers kept the cellulase activity at the background level. It is concluded that in the case of petroleum pollution of infertile soils, the introduction of the upper layers of the phytomass of lowland bogs by providing looseness and long-term supply of nutrients from the dying parts of the moss will accelerate the self-cleaning processes.
\end{abstract}

Keywords: petroleum pollution; ex situ remediation; biostimulation; enzymatic diagnostics

\section{Introduction}

The use of imperfect technology and worn-out equipment for oil extraction, transportation, and processing results in penetration of petroleum into soil and aquatic ecosystems. Usinsk District of the Komi Republic is a region of intensive industrial oil production in the European North. In the autumn of 1994, the largest accident in the entire history of oil pipelines operation occurred on the territory of the Usinsk region of Komi Republic [1]. In total, according to various estimates, from 14 to 150 thousand tons of oil (on an area of up to 700 hectares) was released into the environment [2]. Small oil spills are still occurring. In countries such as Norway, Great Britain, and Canada, petroleum production takes place in similar natural and climatic conditions. Hence, there is a need to develop a set of measures to restore polluted parts of natural objects to their original condition with minimal time consumption. For significant degrees of petroleum pollution, it is rational to use physical and chemical methods to remove most of the oil products that have seeped into the natural environment. Biological methods can be applied in conjunction with physical and chemical ones at the final stages, or independently for relatively small oil contaminations. The biological methods that can be singled out include biostimulation aimed at the activation of autochthonous microorganisms that have preserved their viability under the conditions of anthropogenic impact; bioaugmentation, which involves the introduction of specialized microbial strains; and phytoremediation with the use of plants $[3,4]$. In addition, the scientific basis for zooremediation is being created $[5,6]$. 
The choice of the method of petroleum pollution neutralization may be determined by the economy as well as by the specific features of the object of anthropogenic impact, including the ability to self-recover. Biostimulation is the simplest method of recovery, because it requires only mineral and organic additives. It can be assumed that autochthonous microorganisms are the most resistant to the impact of both biotic and abiotic environmental factors due to natural selection of the most resistant lines in the habitats [7]. For example, it was determined in a study [8] that when adding specialized strains of hydrocarbon-oxidizing microorganisms to petroleum-contaminated loamy-podzolic soil, the biodegradation rate increased only temporarily, which indicates that biostimulation is the best strategy for recovery in the field.

Ex situ remediation allows one to model optimal conditions for total petroleum hydrocarbons (TPH) decomposition, which contributes to faster utilization of pollutants in the soil, as opposed to uncontrolled processes in the natural environment. A study [9] determined that in case of minor pollution (up to $5 \mathrm{~g}$ of TPH per $1 \mathrm{~kg}$ of soil), the concentration of petroleum products in the soil during ex situ remediation decreases by $60-70 \%$ in just 28 days. Another study [10] reported that the decomposition of high-viscosity oil by $50 \%$ took 60 days, with the oil concentration being $50 \mathrm{~g}$ per $1 \mathrm{~kg}$ of soil. The soil was composed of bog peat and biohumus rich in nutrients and microorganisms. A field experiment [11] showed that the degree of decomposition of aliphatic hydrocarbons in the soil contaminated with fuel oil with additional stimulation from both fertilizers and zymogenic microorganism was more than $90 \%$ after 150 days, while in the control soil it was no more than $10 \%$. The experiment was conducted from March to August in an open-air environment with the temperatures ranging between 0 and $35^{\circ} \mathrm{C}$. Another study [12] determined that the remediation of coastal Mediterranean petroleum-contaminated sands (5 $\mathrm{g}$ TPH per $1 \mathrm{~kg}$ of sand) using fertilizers and surfactants contributes to a significant decomposition of n-alkanes and polycyclic aromatic hydrocarbons with two to three rings in 45 days, by $97 \%$ and $95 \%$, respectively. Considering the region of research, a good case may be made for optimal temperature conditions for biological oxidation of $\mathrm{TPH}$ in the open air.

Analyzing the biochemical activity of soils at different stages of self-cleaning facilitates an overall assessment of the processes of transformation of substances by means of microorganisms. In the case of contamination of soils, the assessment of enzymatic activity enables the identification of changes that occurred due to a pollutant, as well as the reaction aimed at changing conditions [13]. On the other hand, the control of biochemical activity allows one to assess the effectiveness of applied methods of remediation at different stages of recovery of petroleum-contaminated soils [8]. Therefore, the analysis of the rates of quantitative change of pollutants in anthropogenic soil, combined with enzymatic biodiagnostics, in most cases can be quite effective in environmental monitoring, although it does not replace microbiological studies.

The aim of this study is to assess the potential of lowland biomass for ex situ remediation technology petroleum-contaminated soils.

\section{Materials and Methods}

\subsection{Soil Types and Ex Situ Remediation Conditions}

Almost $90 \%$ of the territory of the Komi Republic is located in the taiga vegetation zone, where bogs occupy an area of approximately $8 \%$ [14]. The study used as its subject an upper layer of bog soil of up to $10 \mathrm{~cm}$ in depth, which was selected in the vicinity of Syktyvkar. The soil from the lowland marsh was mainly represented by the phytomass, both live and dead, of such mosses as Plagiomnium ellipticum (Brid.) T.J.Kop. and Aulacomnium palustre (Hedw.) Schwaegr. Bog soils fall into the peaty eutrophic soils category, which includes peaty humus (Hemic Histosols (Eutric) and Sapric Histosols (Eutric)) [15]. All soil samples were sampled during early June 2019. $\mathrm{pH}$ was 7.6 bog soils. Bulk density was $0.22 \mathrm{~g}$ per $1 \mathrm{~cm}^{3}$ of soil. The sorption capacity was $4-5 \mathrm{~g}$ of oil per $1 \mathrm{~g}$ of soil. 
Before the experiment, bog soil was grinded and sifted through a sieve with a hole size of $5 \mathrm{~mm}$. Samples weighing $100 \mathrm{~g}$ (humidity 10\%) were then placed in vegetative vessels, and about $5 \mathrm{~g}$ of petroleum (Usinsk field) was added and thoroughly mixed in. The following ex situ remediation options were modeled (Table 1). Option «F-/S-» simulated soil self-cleaning, with only distilled water being added to the sample to establish 20-30\% moisture level. In other experiment options, besides water, additives were introduced to the sample to activate the process of biological oxidation of oil. There were three parallel experiments for each remediation option. Three samples were without oil (background).

Table 1. Remediation options for petroleum-contaminated soil.

\begin{tabular}{ccc}
\hline Options & $\begin{array}{c}\text { Fertilizer (Ammonium } \\
\text { Nitrogen-10\%; Total } \\
\text { Phosphates-25\%; Potassium } \\
\left.\text { in Terms of } \mathrm{K}_{2} \mathrm{O}-25 \%\right), 0.5 \mathrm{~g} \\
\text { per 100 g Soil Sample (F) }\end{array}$ & $\begin{array}{c}\text { Nonionic Surfactant } \\
\text { (Laurylglucoside), 10 mg per } \\
\text { 100 g Soil Sample } \\
\text { (S) }\end{array}$ \\
\hline $\mathrm{F}-/ \mathrm{S}-$ & - & - \\
\hline $\mathrm{F}-/ \mathrm{S}+$ & - & + \\
\hline $\mathrm{F}+\mathrm{S}-$ & + & - \\
\hline $\mathrm{F}+/ \mathrm{S}+$ & + & + \\
\hline
\end{tabular}

Soil samples in the vessels were placed in conditions close to natural (for a period of 90 days), with no exposure to direct sunlight. According to https://www.gismeteo.ru, significant temperature fluctuations were observed in the open air during the whole period of the experiment (Figure 1). The highest temperature fluctuations were observed during June, up to frosts at night. The soil samples were loosened and kept moisture in the range of 20-30\%. During the process of remediation, the samples were taken from the soil vessels after 30,60, and 90 days and dried to air-dry state, and urease and cellulase activities as well as residual TPH content were measured.
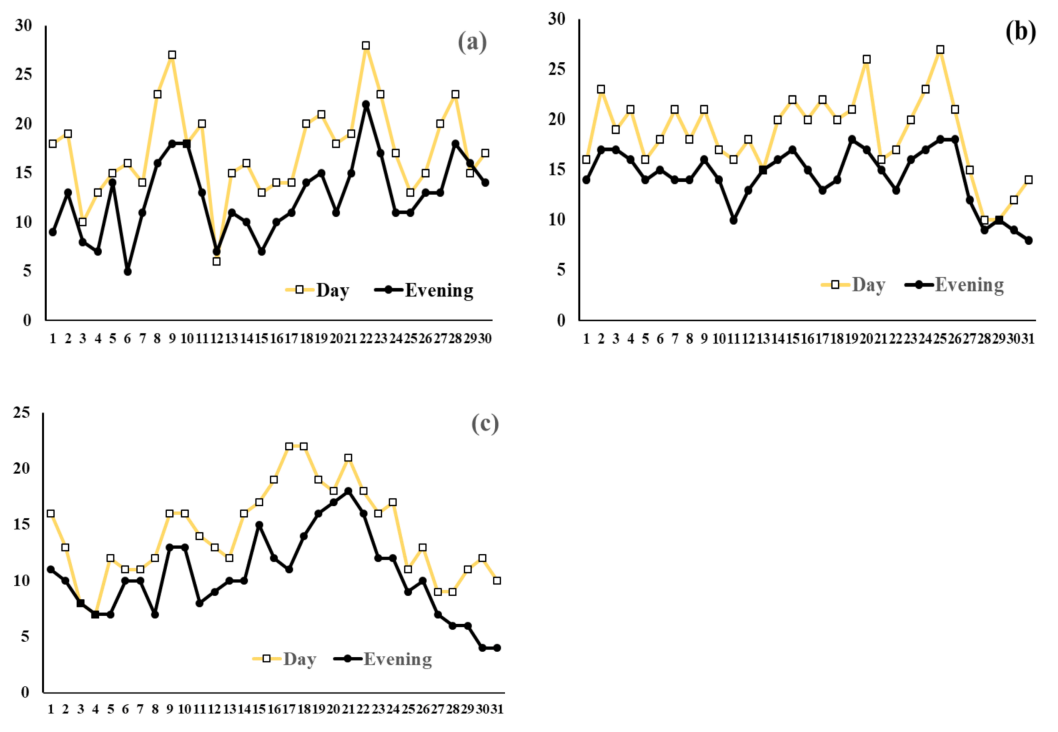

Figure 1. Temperature dynamics for the summer period of 2019 in the vicinity of Syktyvkar: (a) June, (b) July, and (c) August. The ordinate axis is the Celsius scale.

\subsection{Soil Biochemical Activity Analysis}

The method to determine the urease activity [16] was used with some changes. Five $g$ of air-dried soil (humidity 5-6\%) was placed in a $50 \mathrm{~cm}^{3}$ Erlenmeyer flask and treated with $20 \mathrm{~cm}^{3}$ of $\mathrm{H}_{2} \mathrm{O}$ 
containing $3 \%$ of urea and $0.05 \%$ of sodium azide or $20 \mathrm{~cm}^{3}$ of $\mathrm{H}_{2} \mathrm{O}$ with $0.05 \%$ of sodium azide (control). The flasks were capped and incubated at $30{ }^{\circ} \mathrm{C}$ for $24 \mathrm{~h}$. After incubation, 0.1 or $0.2 \mathrm{~cm}^{3}$ of the solution from the flask was placed into a test tube, $1 \mathrm{~cm}^{3}$ of Nessler's reagent was added, and the solution was brought to $10 \mathrm{~cm}^{3}$ with distilled water. The optical density was measured on a KFK-3-01(Russia) photometer at a wavelength of $420 \mathrm{~nm}$. A calibration line was built using ammonium sulfate. One unit of urease activity represented the number of enzymes in $1 \mathrm{~g}$ of the air-dried soil that form $1 \mu \mathrm{g}$ of ammonium ions per hour in the presence of $3 \%$ urea solution.

The method to determine the cellulases activity [17] was used with some changes. One g of air-dried soil (humidity 5-6\%) was placed in a $50 \mathrm{~cm}^{3}$ Erlenmeyer flask and treated with $20 \mathrm{~cm}^{3}$ of $\mathrm{H}_{2} \mathrm{O}$ containing $1 \%$ of carboxymethylcellulose (CMC) and $0.05 \%$ of sodium azide or $20 \mathrm{~cm}^{3} \mathrm{H}_{2} \mathrm{O}$ with $0.05 \%$ of sodium azide (control). The flasks were capped and incubated at $30^{\circ} \mathrm{C}$ for $24 \mathrm{~h}$. After incubation, the reaction mixture was centrifuged at $8000 \mathrm{rpm}$ for $15 \mathrm{~min}$. Further, $1 \mathrm{~cm}^{3}$ of solution was taken and the reducing sugars were determined using the Somogyi-Nelson method [18]. A calibration line was built using glucose. One g per unit of cellulase activity represented the number of enzymes in $1 \mathrm{~g}$ of the soil sample that formed $1 \mu \mathrm{g}$ of reducing sugars per hour in the presence of $1 \% \mathrm{CMC}$.

\subsection{Quantification of the Content of Microscopic Fungi}

For counting the mycelium of microscopic fungi on a Mikmed 2 (version 11) fluorescent microscope, method [19] was used with some changes (camera-RisingCam E3 Sony IMX226 12 MP; software-RisingView. Microscope objective was 40x. After preparing the soil suspension ( $1 \mathrm{~g}$ of soil per $100 \mathrm{~cm}^{3}$ of water), samples were taken in triplicate and the necessary dilution was carried out. Then, without waiting for sedimentation, $3 \mathrm{~cm}^{3}$ of the diluted sample was filtered through a microporous filter with a pore size of $0.2 \mu \mathrm{m}$. The counting was carried out over the entire filtration area in the long-wave ultraviolet range. The excitation wavelength was $\lambda=360 \mathrm{~nm}$, and the fluorescent components of the mycelium were counted in the fluorescence range $\lambda=400-440 \mathrm{~nm}$. In this case, no specific dyes were used. The calculation was carried out in units of mycelium fragments per $1 \mathrm{~g}$ of soil. As a result, the average value of three tests was taken.

\subsection{Assessment of Residual TPH Content}

The content of TPH in soil samples was determined by gravimetric method [20]. To facilitate this, a series of TPH extractions in chloroform from the $2 \mathrm{~g}$ soil sample were sequentially made until a transparent solution was reached. Then, the excess volume of chloroform was evaporated from the resulting extract using a water bath to a final volume of $20 \mathrm{~cm}^{3}$. The residual extract was dried in a fume hood to a constant mass of a dry residue at the temperature of $20^{\circ} \mathrm{C}$. The dry residue was then extracted with hexane, and the resulting solution was transferred to a chromatographic column packed with $6 \mathrm{~g}$ of aluminum oxide. The column was rinsed with $10 \mathrm{~cm}^{3}$ of pure hexane before the insertion of the extract. The volume of hexane used for the extraction of the dry residue was $40 \mathrm{~cm}^{3}$. The resulting eluate was collected in pre-weighed glass jars and dried in a fume hood to constant weight at $20^{\circ} \mathrm{C}$. The TPH content was calculated from the difference between the weight of the empty jar and the jar with the dry residue. All analyses were performed in triplicate for each soil sample.

For all methods, the Microsoft Excel statistical analysis package was used. In particular, «one-way ANOVA» was used.

\section{Results and Discussion}

\subsection{Dynamics of TPH Decomposition}

This experiment revealed that during the first 30 days in natural conditions, the TPH decomposition was $30 \pm 5 \%$ (Figure 2). On days 60 and 90, the TPH decomposition process was $45 \pm 5 \%$ and $60 \pm 5 \%$, respectively. The values of TPH concentration in initial samples (before introduction petroleum) were not more than $0.3 \mathrm{mg} / \mathrm{g}$, and hence were not taken into consideration. It should be noted that heavy 
petroleum was used in the work. In the calculations, only heavy non-volatile petroleum fractions were taken into account, except for tar and asphalt. It was revealed that the introduction of various stimulating additives has an insignificant effect. As a result, no reliable differences $(p>0.05)$ were found in the rate of TPH reduction between different bio-stimulation options.

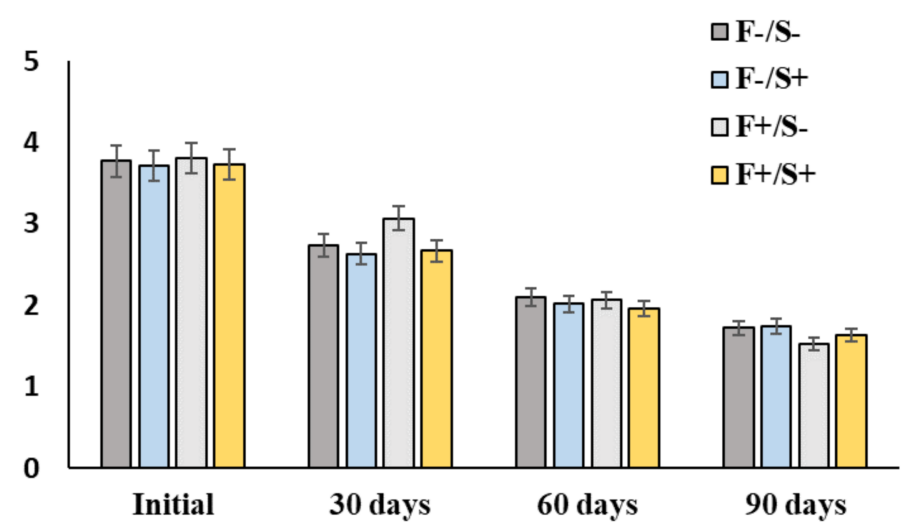

Figure 2. Dynamics of total petroleum hydrocarbons (TPH) concentration changes in soil samples during ex situ remediation. The ordinate axis is the TPH concentration, $\mathrm{g} / 100 \mathrm{~g}$ of soil sample. The zero point represents the data of TPH concentration after introduction petroleum to soil samples.

Reduced temperatures can have a significant impact on the biodegradation of hydrocarbons. For example, a previous study [21] showed that the isolated strain of Pseudoalteromas sp. at low temperatures tended to decompose hydrocarbons mainly with a shorter chain. In another experiment, the biodegradation of hydrocarbons with chain length greater than $\mathrm{C}_{12}$ slowed down sharply at temperatures close to $0^{\circ} \mathrm{C}$ [22]. It was found that the growth of psychrophilic microorganisms requires physiological adaptation, including cold-resistant enzymes. Contrariwise, strains of Rhodococcus sp. and Gordonia sp. have been found to be capable of effective biodegradation of heavy oil even at temperatures of $10^{\circ} \mathrm{C}$ in fertile soil [23].

The natural process of aeration was at a fairly good level in the bog soils, since the soil retained a loose structure. Moreover, according to data from existing publications, the root rhizosphere of bog plants is characterized by a sufficiently large variety of both Gram-positive and Gram-negative bacteria, many of which may act as potential oil degraders [24,25]. For example, in a previous study [26], the soil was taken after contamination with diesel fuel with a concentration of $25 \mathrm{~g}$ of TPH per $1 \mathrm{~kg}$ of soil. Variants of stimulation of TPH decomposition were employed, including allochthonous microorganisms, biosurfactants, and mineral fertilizers. It was found that after 100 days of bioremediation ex situ (at 25-35 ${ }^{\circ} \mathrm{C}, \mathrm{pH}$ 6.2-7.8, humidity 15-20\%), the decomposition of TPH was $80-90 \%$ for the variants using biosurfactants and application of additional microorganisms. Self-cleaning assisted biodegradation by $68 \%$. Based on the obtained data, it was concluded that there was a sufficient number of autochthonous microorganisms in the initial soil that could utilize TPH and only mineral nutrients and biosurfactants were needed.

Another study [27] determined that addition of starch in petroleum-contaminated soil promotes intensification of TPH oxidation processes. The authors conclude that co-metabolism mechanisms are present in the decomposition of TPH. Acceleration of TPH decomposition process was also revealed in [28] when albumin series proteins were added to the soil. From this, we can conclude that the phytomass of the mosses is a rich source of nutrients regardless of the presence of additional additives.

\subsection{Enzymatic and Microbial Diagnostics of Recultivated Bog Soil}

Petroleum contamination causes a qualitative reorganization of the microbial community, and in some cases an increase in the number of specialized oil-oxidizing microorganisms [29,30]. An increase 
in the activity of catalase, dehydrogenase, peroxidase, and polyphenol oxidase is observed [8,11,31]. One of the important biogenic elements is nitrogen, which plays a key role in the formation of the biomass of living organisms. Nitrogen metabolic enzyme activity is an important diagnostic indicator of the intensity of soil nitrogen mobilization processes. It has been noted that urease activity increases with average and sometimes strong petroleum pollution [32], while it decreases with very strong petroleum pollution. However, another study [33] revealed a decrease in the urease activity, which can be influenced by the type of polluting oil, quantity, and type of soil. All these observations suggest that urease activity can be used as a biodiagnostic indicator of petroleum-contamination soils and as a criterion for self-cleaning for various stimulation methods [34].

The introduction of mineral fertilizers for stimulation of TPH decomposition leads to intensification of nitrogen compound metabolism (Figure 3). Almost twofold increase of urease activity was revealed in the first 30 days alone $(p<0.01)$. On the other hand, the surfactant acted more as an inhibitor for microorganisms involved in nitrogen metabolism, even in the presence of mineral fertilizers $(p<0.05)$. It should be noted that the introduced petroleum itself was also an activator of nitrogen metabolism after 30 days $(p<0.01)$. Therefore, it is possible to conclude that there was an adaptation of microbial community to oil pollutants.

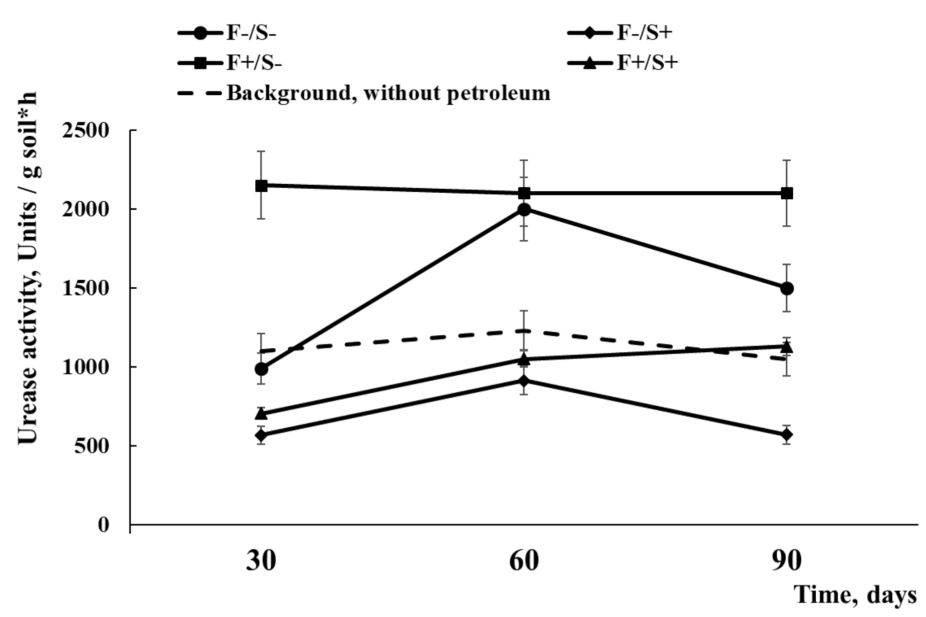

Figure 3. The dynamics of urease activity in bog soil under various options for remediation.

As the objects of the study were soils containing plant residues, it was expedient to check cellulase activity at various stages of ex situ remediation. Cellulose-destroying microorganisms, which are specific producers of cellulases, can react sensitively to petroleum contamination. Depending on the amount of oil, cellulolytic microorganisms remain in a depressed state for a long time after contamination [35]. Therefore, the activity of soil cellulases may serve as an indicator of soil conditions at different stages of self-cleaning as well as after remediation measures.

The addition of mineral fertilizers to petroleum-contaminated bog soil stimulated cellulase activity $(p<0.01)$, while surfactant slightly inhibited them in the early stages $(p>0.05)$ (Figure 4). According to data from existing publications, nonionic surfactants contribute to the increase of cellulase activity [36,37], but in the case of oil contamination due to surfactants, the volume of oil distribution in soil increases, and consequently, sorption occurs in a larger area of cellulose-containing residues, which can lead to the oppression of cellulose microorganisms. The simultaneous addition of surfactants and fertilizers kept the cellulase activity rate at the control level $(p<0.05)$. 


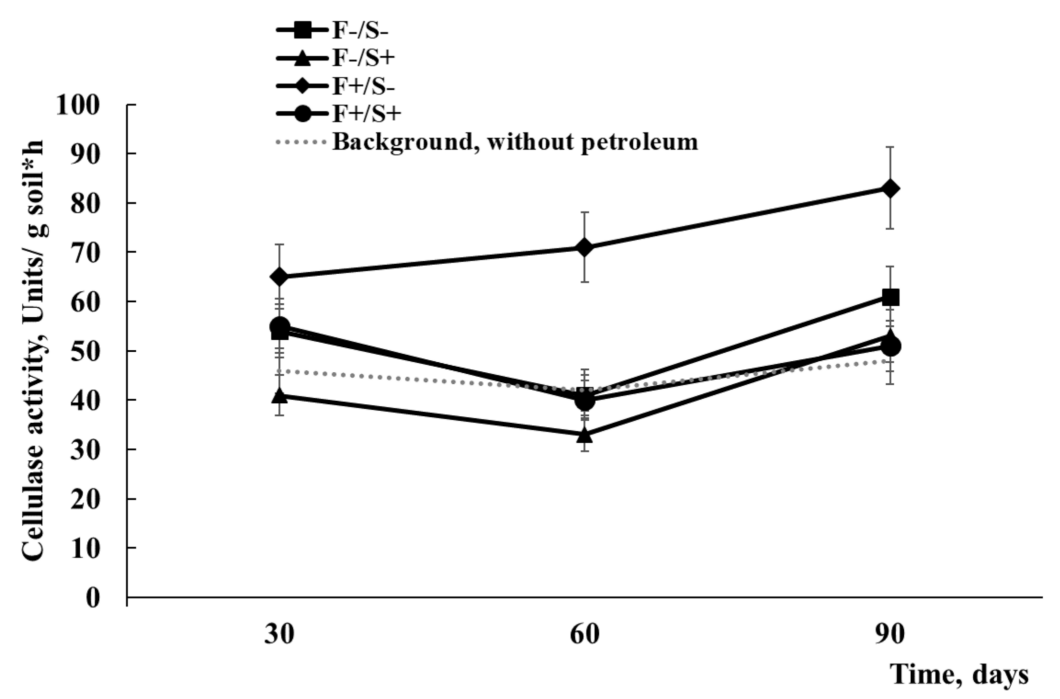

Figure 4. The dynamics of cellulase activity in bog soil under various options for remediation.

The express method of counting elements of microscopic fungi (Figure 5) can provide a concept of the ability of microscopic fungi to fit to petroleum pollution, as well as the effect of additional stimulating additives. In work [38], synergy between fungi and bacteria in the process of hydrocarbon biodegradation is noted. Synergy between fungi and roots of vascular plants [39] allows the use of bog biomass in combination with phytoremediation. Therefore, by the amount of mycelium, one can indirectly adjudicate the potential of the soil for self-cleaning. Soil rich in mycelium can be used for bioremediation of petroleum spills on infertile soils.

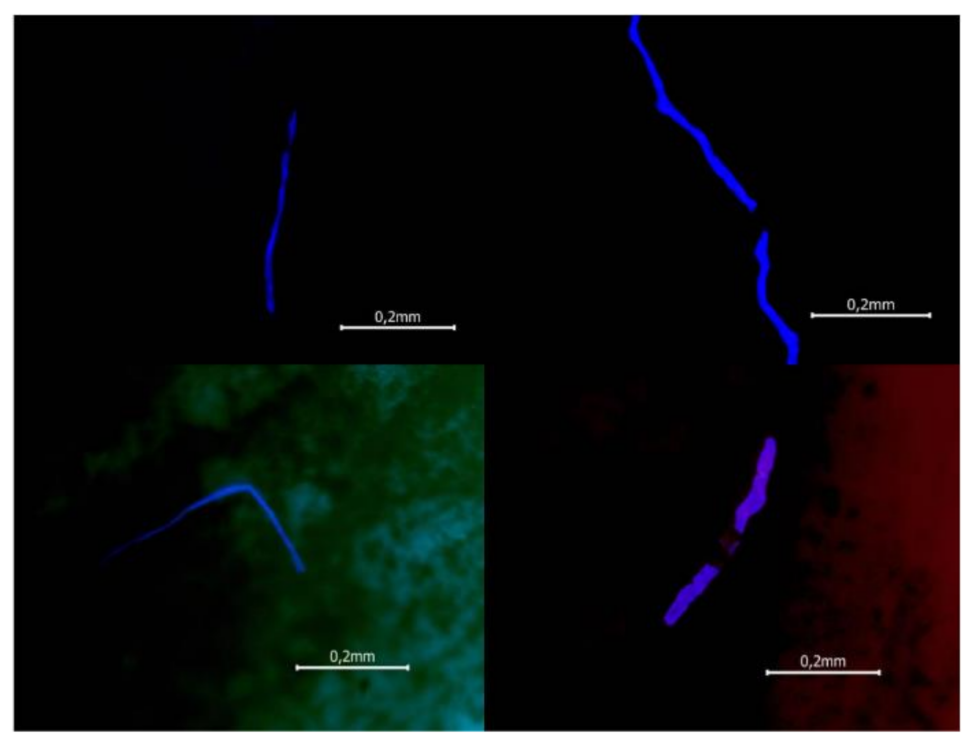

Figure 5. Fragments of fungal mycelium on a microporous filter (microscope objective 40×).

After 90 days, a slight excess of the microscopic fungi content in samples with the addition of mineral fertilizers was revealed compared to others $(p>0.05)$ (Figure 6). Accelerated counting of living bacterial cells using vital dyes (fluorescein diacetate, acridine orange) has caused difficulties due to significant fluorescence of petroleum and soil components. Therefore, for a comfortable counting of bacterial cells, it is necessary to create conditions with a maximum decrease in background fluorescence. 


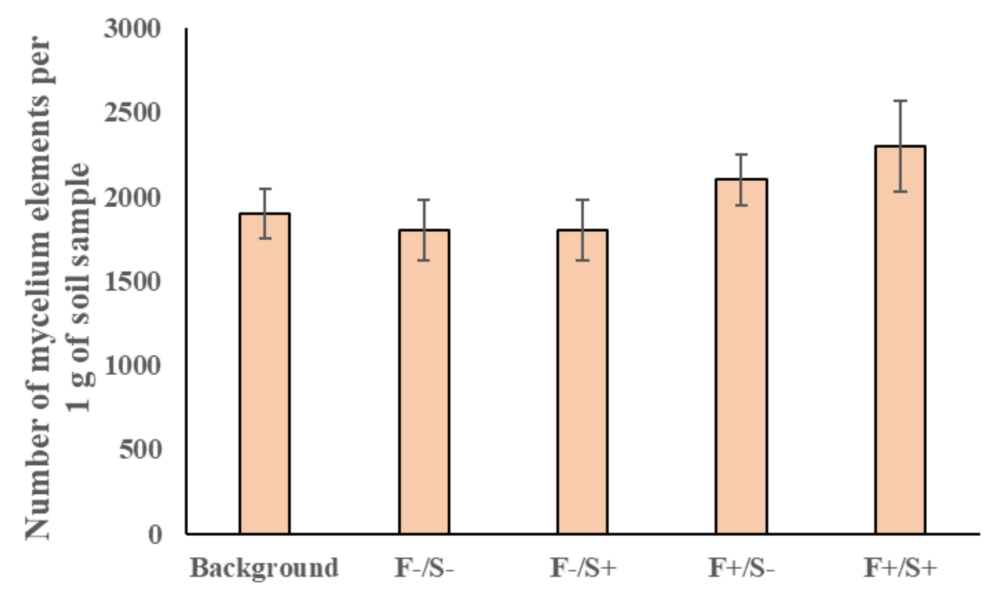

Figure 6. Quantitative characteristic of the microscopic fungi content.

In general, biochemical and microbial indicators can show an approximate state of the soils under the influence of pollutants. Soil type as well as the presence of bioavailable organic parts can significantly influence the self-cleaning processes of petroleum-contaminated soils $[8,10,26]$. Data from existing publications can attest to the fact that the presence of easily digestible organic parts in the soil makes for the most effective self-cleaning due to autochthonous microorganisms [40,41]. For remediation process in hard-to-reach northern latitudes, the main source of available organic matter can be the upper vegetation cover of the bogs.

Previous research publications have long suggested the use of peat, especially raised bog peat, as effective means of petroleum pollution elimination due to its hydrophobic nature [42-44]. However, to use the peat, preliminary preparations such as $\mathrm{pH}$ raising or introduction of activators are required. It was found that soil samples of lowland bogs were quite effective for biological petroleum oxidation, even without preliminary treatment. Moreover, it can be predicted that in the case of oil contamination of sandy or clayey soils, especially those with strong acidity, the introduction of the upper layers of the phytomass of lowland bogs by providing the friability and prolonged supply of nutrients from the dying parts of the moss will accelerate the self-cleaning process.

In conclusion, the bog soil showed the good potential for self-cleaning for the whole period of the experiment. In bog soil samples, the application of mineral fertilizers contributed to an increase in urease and cellulase activities, while the application of nonionic surfactants led to their insignificant decrease. The application of surfactants to emulsify fresh oil spills can lead to a negative effect from solubilization of low molecular weight oil fractions. Therefore, it is more appropriate to use surfactants for old oil spills. It was concluded that the most important factor for the intensification of oil biodegradation is the presence of easily assimilable organic components in the soil, which activate co-metabolism processes during biological petroleum oxidation. The phytomass of a lowland bog contains a sufficient titer of oil-degrading microorganisms; therefore, it is a good alternative to biological products for bioremediation of petroleum spills. At the same time, to identify the problems and limitations of this technology, it is necessary to conduct a full-fledged experiment in the oil-contaminated area. It is also necessary to assess the effect of direct sunlight on the bioremediation process. Due to typical oil degraders such as Pseudomonas sp., Bacillus sp., Rhodococcus sp., Micrococcus sp., and Pseudoalteromas sp., however, metagenomic analysis will provide a complete picture of the successional rearrangements of microbial communities during bioremediation.

Funding: This study was carried out with financial support from RFBR, Project No. 18-29-05028 mk «biological methods of oil spill response in the European Subarctic: the role of microbiological preparations, bioremediation, efficiency assessment, ecosystem dynamics», and partial financial support: AAAA-A17-117121270025-1.

Conflicts of Interest: The author declares no conflict of interest. 


\section{References}

1. Barenboim, G.; Ertsev, G.; Taskaev, A.I.; Ulyashev, A.I.; Shubin, Y.P. Environmental Monitoring in the Accident Area. Experience of Elimination of Oil Spills in the Usinsk District of the Komi Republic; Syktyvkar: Komimeliovodkhozproject, Russia, 2000; pp. 83-146. (In Russian)

2. Shoba, S.A.; Yakovlev, A.S.; Rybalsky, N.G. (Eds.) Ecological Standardization and Regulation of Environmental and Soils Quality and Land Management; NIA-Priroda: Moscow, Russian, 2013; 373p. (In Russian)

3. Si-Zhong, Y.; Hui-Jun, J.; Zhi, W.; Rui-Xia, H.; Yan-Jun, J.; Xiu-Mei, L.; Shao-Peng, Y. Bioremediation of Oil Spills in Cold Environments: A Review. Pedosphere 2009, 19, 371-381.

4. Chaudhary, D.K.; Kim, J. New insights into bioremediation strategies for oil-contaminated soil in cold environments. Int. Biodeterior. Biodegrad. 2019, 142, 58-72. [CrossRef]

5. Schaefer, M.; Petersen, S.O.; Filser, J. Effects of Lumbricus terrestris, Allolobophora chlorotica and Eisenia fetida on microbial community dynamics in oil-contaminated soil. Soil Biol. Biochem. 2005, 37, 2065-2076. [CrossRef]

6. Zhou, J.; Chen, D.; Huang, R.; Huang, G.; Yuan, Y.; Fan, H. Effects of bacterial-feeding nematodes on soil microbial activity and the microbial community in oil-contaminated soil. J. Environ. Manag. 2019, 234, 424-430. [CrossRef] [PubMed]

7. Fodelianakis, S.; Antoniou, E.; Mapelli, F.; Magagnini, M.; Nikolopoulou, M.; Marasco, R.; Barbato, M.; Tsiola, A.; Tsikopoulou, I.; Giaccaglia, L.; et al. Allochthonous bioaugmentation in ex situ treatment of crude oil-polluted sediments in the presence of an effective degrading indigenous microbiome. J. Hazard. Mat. 2015, 287, 78-86. [CrossRef] [PubMed]

8. Polyak, Y.M.; Bakina, L.G.; Chugunova, M.V.; Mayachkina, N.V.; Gerasimov, A.O.; Bure, V.M. Effect of remediation strategies on biological activity of oil-contaminated soil-A field study. Int. Biodet. Biodegr. 2018, 26, 57-68. [CrossRef]

9. Lin, T.-C.; Pan, P.-T.; Cheng, S.-S. Ex situ bioremediation of oil-contaminated soil. J. Haz. Mat. 2010, 176, 27-34. [CrossRef]

10. Filatov, D.A.; Gulaya, E.V.; Svarovskaya, L.I.; Altunina, L.K. Biochemical Oxidation of High Viscosity Oil by Indigenous Soil Microflora. Pet. Chem. 2013, 53, 59-64. [CrossRef]

11. Beškoski, V.P.; Gojgic-Cvijovic, G.; Milic, J.; Ilic, M.; Miletic, S.; Šolevic, T.; Vrvic, M.M. Ex situ bioremediation of a soil contaminated by mazut (heavy residual fuel oil)—A field experiment. Chemosphere 2011, 83, 34-40. [CrossRef]

12. Nikolopoulou, M.; Pasadakis, N.; Norf, H.; Kalogerakis, N. Enhanced ex situ bioremediation of crude oil contaminated beach sand by supplementation with nutrients and rhamnolipids. Mar. Pollut. Bull. 2013, 77, 37-44. [CrossRef]

13. Utobo, E.B.; Tewari, L. Soil enzymes as bioindicators of soil ecosystem status. Appl. Ecol. Environ. Res. 2015, 13, 147-169.

14. Taskaev, A.I. (Ed.) Virgin Forests of Komi: The UNESCO World Cultural and Natural Heritage Site; Publishing Centre Design, Information, Cartography: Moscow, Russia, 2006; 288p. (In Russian)

15. World Reference Base for Soil Resources 2014: International Soil Classification System for Naming Soils and Creating Legends for Soil Maps; World Soil Resources Report; Food and Agriculture Organization of the United Nations: Rome, Italy, 2015; 106p.

16. Tabatabai, M.A.; Bremner, J.M. Assay of urease activity in soils. Soil. Biol. Biochem. 1972, 4, 479-487. [CrossRef]

17. Pancholy, S.K.; Rice, E.L. Soil enzymes in relation to old field succession: Amylase, cellulase, invertase, dehydrogenase, and urease. Soil Sci. Soc. Am. J. 1973, 37, 47-50. [CrossRef]

18. McCleary, B.V.; McGeough, P. A comparison of polysaccharide substrates and reducing sugar methods for the measurement of endo-1,4- $\beta$-xylanase. Appl. Biochem. Biotech. 2015, 177, 1152-1163. [CrossRef]

19. Polyanskaya, L.M.; Pinchuk, I.P.; Stepanov, A.L. Comparative Analysis of the Luminescence Microscopy and Cascade Filtration Methods for Estimating Bacterial Abundance and Biomass in the Soil: Role of Soil Suspension Dilution Eurasian Soil Science. Eurasian Soil Sci. 2017, 50, 1173-1176. [CrossRef]

20. Tarabukin, D.V.; Torlopov, M.A.; Shchemelinina, T.N.; Anchugova, E.M.; Shergina, N.N.; Istomina, E.I.; Belyy, V.A. Biosorbents based on esterified starch carrying immobilized oil-degrading microorganisms. J. Biotech. 2017, 260, 31-37. [CrossRef] 
21. Lin, X.; Yang, B.; Shen, J.; Du, N. Biodegradation of Crude Oil by an Arctic Psychrotrophic Bacterium Pseudoalteromomas sp. P29. Curr. Microbiol. 2009, 59, 341-345. [CrossRef]

22. Vergeynst, L.; Kjeldsen, K.U.; Lassen, P.; Rysgaard, S. Bacterial community succession and degradation patterns of hydrocarbons in seawater at low temperature. J. Haz. Mat. 2018, 353, 127-134. [CrossRef]

23. Shintani, M.; Sugiyama, K.; Sakurai, T.; Yamada, K.; Kimbara, K. Biodegradation of A-fuel oil in soil samples with bacterial mixtures of Rhodococcus and Gordonia strains under low temperature conditions. J. Biosci. Bioeng. 2019, 127, 197-200. [CrossRef]

24. Daane, L.L.; Harjono, I.; Zylstra, G.J.; Häggblom, M.M. Isolation and characterization of polycyclic aromatic hydrocarbon-degrading bacteria associated with the rhizosphere of salt marsh plants. Appl. Environ. Microbiol. 2001, 67, 2683-2691. [CrossRef]

25. Escalante-Espinosa, E.; Gallegos-Martínez, M.E.; Favela-Torres, E.; Gutiérrez-Rojas, M. Improvement of the hydrocarbon phytoremediation rate by Cyperus laxus Lam. inoculated with a microbial consortium in a model system. Chemosphere 2005, 59, 405-413. [CrossRef] [PubMed]

26. Lin, T.C.; Pan, P.T.; Young, C.C.; Chang, J.S.; Chang, T.C.; Cheng, S.S. Evaluation of the optimal strategy for ex situ bioremediation of diesel oil-contaminated soil. Environ. Sci. Pollut. Res. 2011, 18, 1487-1496. [CrossRef] [PubMed]

27. Karimi, M.; Biria, D. The synergetic effect of starch and alpha amylase on the biodegradation of n-alkanes. Chemosphere 2016, 152, 166-172. [CrossRef] [PubMed]

28. Hong, J.-K.; Jho, E.H.; Choi, H.S.; Kang, G. Role of hemoglobin in hemoglobin-based remediation of the crude oil-contaminated soil. Sci. Total Environ. 2018, 627, 1174-1181. [CrossRef] [PubMed]

29. Abed, R.M.M.; Al-Kindi, S. Effect of disturbance by oil pollution on the diversity and activity of bacterial communities in biological soil crusts from the Sultanate of Oman. Appl. Soil Ecol. 2017, 110, 88-96. [CrossRef]

30. Ansari, N.; Hassanshahian, M.; Ravan, H. Study the Microbial Communities' Changes in Desert and Farmland Soil After Crude Oil Pollution. Int. J. Environ. Res. 2018, 12, 391-398. [CrossRef]

31. Melekhina, E.N.; Markarova, M.Y.; Shchemelinina, T.N.; Anchugova, E.M.; Kanev, V.A. Secondary successions of biota in oil-polluted peat soil upon different biological remediation methods. Eurasian Soil Sci. 2015, 48, 643-653. [CrossRef]

32. Petrov, A.M.; Versioning, A.A.; Karimullin, L.K.; Akaikin, D.V.; Tarasov, O.Y. Dynamics of Ecological and Biological Characteristics of Soddy-Podzolic Soils under Long-Term Oil Pollution. Eurasian Soil Sci. 2016, 49, 784-791. [CrossRef]

33. Kolesnikov, S.I.; Tatosyan, M.L.; Aznaur'yan, D.K. Change in Enzymatic Activity of Common Chernozem Polluted with Crude Oil and Its Products in Model Experiments. Russ. Agric. Sci. 2007, 33, 318-320. [CrossRef]

34. Kiss, S.; Drăgan-Bulard, M.; Paşca, D. Enzymology of the Recurvation of Technogenic Soils. In Advances in Agronomy; Academic Press: Cambridge, MA, USA, 1989; Volume 42, pp. 229-278.

35. Zhang, X.; Liu, Z.; Luc, N.T.; Liang, X.; Liu, X. Dynamics of the biological properties of soil and the nutrient release of Amorpha fruticosa L. litter in soil polluted by crude oil. Environ. Sci. Pollut. Res. 2015, 22, 16749-16757. [CrossRef]

36. Ooshima, H.; Sakata, M.; Harano, Y. Enhancement of enzymatic hydrolysis of cellulose by surfactant. Biotechnol. Bioeng. 1986, 11, 1727-1734. [CrossRef] [PubMed]

37. Lou, H.; Zeng, M.; Hu, Q.; Cai, C.; Lin, X.; Qiu, X.; Yang, D. Nonionic surfactants enhanced enzymatic hydrolysis of cellulose by reducing cellulase deactivation caused by shear force and air-liquid interface. Bioresour. Technol. 2018, 249, 1-8. [CrossRef] [PubMed]

38. Li, Y.-Q.; Liu, H.-F.; Tian, Z.-L.; Zhu, L.-H.; Wu, Y.-H.; Tang, H.-Q. Diesel pollution biodegradation: Synergetic effect of Mycobacterium and Filamentous Fungi. Biomed. Environ. Sci. 2008, 21, 181-187. [CrossRef]

39. Asemoloye, M.D.; Ahmad, R.; Jonathan, S.G. Synergistic action of rhizospheric fungi with Megathyrsus maximus root speeds up hydrocarbon degradation kinetics in oil polluted soil. Chemosphere 2017, 187, 1-10. [CrossRef] [PubMed]

40. Sheu, Y.-T.; Tsang, D.C.W.; Dong, C.-D.; Chen, C.-W.; Luo, S.-G.; Kao, C.-M. Enhanced bioremediation of TCE-contaminated groundwater using gamma poly-glutamic acid as the primary substrate. J. Clean. Prod. 2018, 178, 108-118. [CrossRef]

41. Agamuthu, P.; Tan, Y.S.; Fauziah, S.H. Bioremediation of hydrocarbon contaminated soil using selected organic wastes. Procedia Environ. Sci. 2013, 18, 694-702. [CrossRef] 
42. Mathavan, G.N.; Viraraghavan, T. Use of peat in the treatment of oily waters. Water Air Soil Pollut. 1989, 45, $17-26$.

43. Galiulin, R.V.; Bashkin, V.N.; Galiulina, R.A. Degradation of Petroleum Hydrocarbons in Soil under the Action of Peat Compost. Solid Fuel Chem. 2012, 46, 328-329. [CrossRef]

44. Cojocaru, C.; Macoveanu, M.; Cretescu, I. Peat-based sorbents for the removal of oil spills from water surface: Application of artificial neural network modeling. Coll. Surf. A Phys. Eng. Asp. 2011, 384, 675-684. [CrossRef]

(C) 2020 by the author. Licensee MDPI, Basel, Switzerland. This article is an open access article distributed under the terms and conditions of the Creative Commons Attribution (CC BY) license (http://creativecommons.org/licenses/by/4.0/). 